\title{
EDITORIAL
}

\section{LAS VIOLENCIAS EN LA FORMACIÓN MÉDICA}

\author{
SANDRA PATRICIA MORENO REALPHE ${ }^{1^{*}}$, Médica MSc. \\ PABLO ALFONSO SANABRIA FERRAND ${ }^{2}$, Psicólogo, Epidemiólogo, MSc. \\ LUIS ARTEMO GONZÁLEZ QUEVEDO ${ }^{3}$, Psicólogo, Epidemiólogo, MSc. \\ CLAUDIA LUCÍA VALENCIA CEDEÑO, Psicóloga, Especialista en Psicología Clínica, MSc. \\ DOCENTES INVESTIGADORES FACULTAD DE MEDICINA. \\ UNIVERSIDAD MILITAR NUEVA GRANADA. \\ BOGOTÁ, COLOMBIA
}

\begin{abstract}
Resumen
El grupo de Salud y Comportamiento de la Facultad de Medicina y Ciencias de la Salud, ha orientado sus investigaciones en la caracterización de las violencias en el entorno educativo de la medicina a nivel institucional y nacional. El presente artículo hace referencia a los hallazgos de los estudios realizados con relación a la temática Bullying y la Violencia basada en el Género, e invita a una reflexión acerca de la importancia de hacer aplicables dichos resultados a la cotidianidad de los procesos educativos; generando estrategias que lleven a la construcción de una Universidad Saludable.
\end{abstract}

Palabras clave: Educación médica. Violencia. Derechos humanos. Política Social. Género.

\section{Introducción}

En Colombia la Constitución Política hizo referencia a la Educación como un derecho de la persona y un servicio público que tiene una función social. Así mismo, "esta educación debe formar al colombiano en el respeto por los derechos humanos, la paz y la democracia..."(1). La Ley 30 de 1992 por su parte, planteó que la Educación Superior es un proceso continuo y que va dirigido al desarrollo de las potencialidades del ser humano de manera integral (2).

Más específicamente en la carrera de medicina, la Federación Médica Mundial generó tres documentos básicos acerca de los estándares globales de la Educación Médica. Con relación al apoyo estudiantil, centró su atención en los procesos de consejería de tipo académico y social, los cuales deben ser garantizados a través de un sistema que facilite el acceso al soporte, al consejo y a la orientación profesional. Dicho consejo basado en el seguimiento del progreso en la formación, en la información sobre problemas que puedan surgir, y estar dirigido a satisfacer las necesidades sociales y personales de los y las estudiantes (3).
En el año 2011 la Asociación Médica Americana (4) realizó una junta cuyo objetivo principal fue analizar estrategias para la optimización del ambiente de aprendizaje, y profundizó acerca de la temática violencia (misstreatment), definiéndola como el comportamiento intencional o no, que muestra falta de respeto por la dignidad de otros $e$ interfiere sin razón con el proceso de aprendizaje. Incluyeron como ejemplos el acoso sexual, la discriminación o acoso basados en raza, religión, etnia, género u orientación sexual, el castigo físico o psicológico y el uso de evaluación y otras formas de asesoría de una manera punitiva.

La Junta presentó resultados del año 2010 y 2011, con una prevalencia entre el 11 y el $40 \%$ de maltrato, concordantes con estudios presentados anteriormente en Estados Unidos y otros países (5-8). Lo que quiere decir que previo al pronunciamiento de la Asociación Médica Americana, la Violencia contra las y los estudiantes en los programas de pregrado y posgrado de medicina ha sido estudiada por diversos autores (9-11), quienes afirmaron que los y las profesionales en medicina son susceptibles de experimentar y así mismo, perpetrar abuso y discriminación. 
Un ejemplo de ello fue la Universidad de Mc Master en Canadá (12), que en el año 1996, realizó un estudio acerca de la prevalencia de la violencia en estudiantes de medicina. Específicamente para la violencia contra la mujer se encontró una prevalencia del 71\%, para la violencia secundaria a su orientación sexual se presentó en un 10.2\%, para acoso sexual se reportó en un $92.2 \%$ y para violencia física, un hallazgo no esperado por los investigadores, estuvo en el 54\%. Este estudio propuso iniciativas educativas, comportamentales y estructurales para incorporar en los programas de formación médica para erradicar estas prácticas.

Otros estudios han relacionado la Violencia basada en el Género (VBG) con la aplicación de la escala de Burnout de Maslach y el inventario de Leymman de terror psicológico en los estudiantes de posgrados médicos (13), encontrando que estas condiciones se presentaban de igual manera en hombres y mujeres pero que hay un mayor grado de despersonalización en mujeres que en hombres.

En 2003, se realizó un estudio de prevalencia de VBG en estudiantes de medicina de seis facultades en Japón (14), encontrando que el 68.5\% de los participantes refirió algún tipo de violencia. Para el caso de VBG, por su condición de ser mujer, se presentó el acoso sexual en el 51.4\% de las estudiantes. No se exploró la violencia por creencias, orientación sexual o raza.

Desde una perspectiva conceptual diferente, en el año 2007, el grupo de salud y comportamiento de la Facultad de Medicina de la Universidad Nueva Granada planteó el estudio nacional de Bullying o intimidación (15) que contó con la participación de 22 facultades de medicina a nivel nacional. Los resultados observados en este estudio confirmaron la presencia de episodios de intimidación en el ámbito de la educación superior y más específicamente, en los estudiantes de las escuelas de medicina del país en un $19,68 \%$. Este dato fue suficiente para dar una voz de alarma a las directivas, docentes y estudiantes, evidenciando que este tipo de fenómenos no son un mito, sino una realidad que se está tomando los ambientes educativos de educación médica en Colombia.

En la misma línea, se realizó el estudio que caracterizó la Violencia basada en el Género en los y las estudiantes de la Universidad Militar Nueva Granada (16) identificando que es una problemática presente y que dista de ser un hecho aislado o sutil. El 94\% de las personas que dieron respuesta al cuestionario y que refirieron haber percibido Violencia basada en el Género, fueron por su sexo, en este caso, el ser mujer. Lo que evidenció la importancia de analizar las condiciones de la violencia contra la mujer en los diferentes ámbitos.
De forma paralela en los últimos años, se han generado Políticas Públicas (17) relacionadas con la promoción de la salud en los entornos educativos. Esta estrategia se denominó Universidad Saludable o Universidad Promotora de Salud. La cual definió a dichas instituciones como aquellas que a través de la distribución social del conocimiento, realizan acciones estratégicas y sostenidas que fomentan la salud integral (biopsicosocial) y la participación activa de la comunidad universitaria. Lo anterior desarrollando una cultura de salud integral, incluyendo la formación de estilos de vida saludable y de autocuidado, así como oportunidades y entornos de vida, trabajo y aprendizaje saludable, investigación y docencia dentro de sus funciones sustantivas" (18).

La estrategia se soportó en las directrices internacionales (Ver Tabla No.1), teniendo como punto de partida la Declaración de Alma Ata, Salud para todos, la cual visibilizó a la salud como un derecho fundamental y planteó la necesidad de establecer acciones a nivel social y económico para el logro de la misma, hasta la conformación de Redes de Universidades Promotoras de Salud que se encuentran desarrollando grandes avances en este ámbito. A nivel nacional la red de Universidades Promotoras (RED CUPS), ha logrado integrar a las Instituciones de Educación Superior y elaboraron un documento marco orientado a la sensibilización y apoyo institucional (19), de igual manera asesoraron la construcción de los lineamientos para la Política a nivel nacional (20). Las temáticas que desarrollan en la actualidad son alimentación sana, actividad física, libres de cigarrillo, consumo de sustancias, sexualidad e inclusión. Sin embargo, no se evidenció la presencia de actividades concretas que vayan orientadas a la promoción de los derechos a la integridad física y mental que se ven vulnerados en situación de intimidación o en situaciones de violencia basada en el género.

\section{Discusión}

Existen mecanismos regionales y nacionales orientados a promover entornos saludables y seguros en los procesos de enseñanza de la Educación Superior, hay esfuerzos reconocidos para organizar las Instituciones Educativas de Educación Superior a nivel nacional. La Universidad Militar Nueva Granada como institución participa activamente en dicha red (Red de Universidades Promotoras de Salud). Sin embargo, al revisar detenidamente sus documentos marco, sus lineamientos y proyectos, estos están principalmente enfocados a los estilos de vida saludable (actividad física, prevención del uso de sustancias psicoactivas, discriminación y salud sexual y reproductiva) pero no abordan el tema del derecho a una vida libre de violencia como parte de dichos estilos de vida. Lo que tampoco se ve reflejado en actividades puntuales o acciones estratégicas. 
Tabla 1. Listado de directrices nacionales e internacionales que dan soporte a la política de Universidad Saludable en Colombia.

\section{Directrices Internacionales:}

- Declaración de Estocolmo sobre el Medio Ambiente Humano 1972

- Declaración de Alma Ata Salud para todos,1978

- Protocolo de Kioto de la Convención Marco de Naciones Unidas sobre el Cambio Climático (CMNUCC) 1987

- Segunda Conferencia Internacional de Promoción de la Salud 1.988

- Carta de Ottawa Primera Conferencia Internacional sobre la Promoción de la Salud 21 de noviembre de 1986

- Declaración de la Conferencia Internacional de Promoción de la Salud, Santa Fe de Bogotá 1992

- Carta del Caribe para la Promoción de la Salud 1.993

- Declaración de Yakarta sobre la Promoción de la Salud en el Siglo XXI 1.997

- Conferencias de Naciones Unidas sobre el Medio Ambiente y el Desarrollo 1992 y 2002

- Quinta Conferencia Mundial de Promoción de la Salud 2000

- Convenio Marco de la OMS para el Control del Tabaco, Resolución WHA 56.1. 2003

- Carta de Bangkok para la Promoción de la Salud 2005

- Informe del IV Congreso Internacional de Universidades Promotoras de la Salud 2009

Se han realizado estudios para caracterizar las violencias al interior de la facultad de medicina respondiendo a los lineamientos de la Federación Médica Mundial y la Asociación Médica Americana, encontrando que, tanto la intimidación o matoneo como la violencia basada en el género, son condiciones presentes en nuestro contexto.

Todo lo anterior plantea un reto en la integración desde la Política Pública de la Promoción de la Salud y la inclusión de actividades específicas orientadas a promover el derecho a vivir sin violencia en las comunidades académicas.

\section{Conflictos de interés}

Los autores declaran no tener de manera directa o indirecta, ningún tipo de conflicto de intereses financieros, académicos o laborales que puedan poner en peligro la validez de este estudio.

\section{Financiación}

Este trabajo se realizó con el apoyo financiero de la Universidad Militar Nueva Granada.

\section{Referencias}

1. Constituyente AN. Constitución Política de Colombia. Colombia: UNESCO; 1991 p. Titulo II, Capitulo II, Articulo 67.

2. Ministerio de Educación Nacional. Ley 30 de Diciembre 28 de 1992. Colombia: Secretaria del Senado; 1992; p. 1.

3. Federación Mundial de Educación Médica. Estándares globales de la WFME para la Educación Médica. Educ Medica. 2004;7(2):5-60.

4. Rappley M. Section on Medical Schools. In: Optimizing the Learning Environment: Exploring the Issue of Medical Student Mistreatment [Internet]. Joint Education Program with the AMA Medical Student Section and AMA the Council on Medical Education; 2011; p. 2-14.

5. Arimatsu M, Wada K, Yoshikawa T, Oda S, Taniguchi H, Aizawa $\mathrm{Y}$, et al. An epidemiological study of work-related violence experienced by physicians who graduated from a medical school in Japan. J Occup Health [Internet]. 2008;50(4):357-61.

6. Baldwin D, Daugherty S, Eckenfels E. Student Perceptions of Mistreatment and Harassment During Medical School A Survey of Ten United States Schools. West J Med. 1991;(155):140-5.

7. Cook DJ, Liutkus JF, Risdoni CL, Griffith LE, Guyatt GH, Walter S. Resident's experience of abuse, discrimination and sexual harassment during residency training. Can Med Assoc J. 1996;154(11):1657-65.

8. Risberg G, Johansson EE, Westman G, Hamberg K. Gender in medicine - An issue for women only? A survey of physician teachers ' gender attitudes. Int J Equity Health. 2003;8:1-8.

9. Moreno-Cubillos C, Osorio-Gómez L, Sepúlveda-Gallego LE. Violencia sexual contra las estudiantes de la Universidad de Caldas. Estudio de corte transversal. Rev colomb Obs ginecol. 2007;58(2):116-23

10. Morgan JF, Porter S. Sexual harassment of psychiatric trainees: experiences and attitudes. Postgrad Med J [Internet]. 1999;75(885):410-3.

11. Gadomski a M, Wolff D, Tripp M, Lewis C, Short LM. Changes in health care providers' knowledge, attitudes, beliefs, and behaviors regarding domestic violence, following a multifaceted intervention. Acad Med [Internet]. 2001;76(10):1045-52.

12. Margittai KJ, Moscarello R, Rossi MF. Forensic aspects of medical student abuse: a Canadian perspective. Bull Am Acad Psychiatry Law [Internet]. 1996 ;24(3):377-85. 
13. Dikmeta E, Top M, Ergin G. An examination of mobbing and burnout of residents. Turkish $\mathrm{J}$ psychiatry [Internet]. 2011;22(3):137-49.

14. Nagata-Kobayashi S, Sekimoto M, Koyama H, Yamamoto W, Goto E, Fukushima O, et al. Medical student abuse during clinical clerkships in Japan. $J$ Gen Intern Med [Internet]. 2006;21(3):212-8.

15. Paredes O, Sanabria-Ferrand P, González-Quevedo L, Moreno-Realphe S. "Bullying" en las facultades de medicina colombianas, mito o realidad. Rev Med. 2010;18(49):161-72.

16. Moreno-Realphe S, Sanabria-Ferrand P, Gonzalez-Quevedo L, Valencia-Cedeño C. ¿"Sutilezas" de la discriminación y la violencia basada en el género ? Situación de los y las estudiantes de pregrado y posgrado de una facultad de medicina en Bogotá D.C. Rev Med [Internet]. 2015;23(1):29-39.

17. Ministerio de Salud. Documento técnico: Promoviendo universidades saludables. Lima; 2010.

18. Universidad Colima. Propuesta de Modelo Nacional de Universidad Saludable Prevenimss. México; 2007.

19. Red Cups. Documento orientador. Bogota, Colombia; 2009

20. Ministerio de Salud y Protección Social C. Universidades e Instituciones de Educación Superior (IES) Promotoras de Salud. Guía para su fortalecimiento y evaluación. Bogotá; 2012. 


\title{
VIOLENCE DURING MEDICAL TRAINING
}

\author{
SANDRA PATRICIA MORENO REALPHE ${ }^{1^{*}}$, MD MSc. \\ PABLO ALFONSO SANABRIA FERRAND ${ }^{2}$, Psychologist, Epidemiologist, MSc. \\ LUIS ARTEMO GONZÁLEZ QUEVEDO ${ }^{3}$, Psychologist, Epidemiologist, MSc. \\ CLAUDIA LUCÍA VALENCIA CEDEÑO象, Psychologist, Specialist in Clinical Psychology, MSc. \\ MEDICAL SCHOOL FACULTY RESEARCHERS. \\ UNIVERSIDAD MILITAR NUEVA GRANADA. \\ BOGOTÁ, COLOMBIA
}

\begin{abstract}
Summary
The Health and Behaviour Group from the Medical and Health Sciences, had guided their research in the characterization about violence in the educational medical enviroment at institutional and national level. The present article makes reference about the findings made by studies with the bullying and gender violence thematic relation, and invites to a reflexion about the importance of apply such results on everyday's educational process, creating strategies to build a Healthy University.
\end{abstract}

Keywords: Medical Education. Violence. Human Rights. Social Politics. Gender.

\section{Introduction}

In Colombia the Political Constitution made reference to Education as a right to the person and a public service with a social function. Likewise, "this education must form the Colombian citizen the respect for human rights, peace and democracy... "(1). Meanwhile, 30th Law of 1992 It stated that higher education is an ongoing process and it is directed to the development of human potential comprehensively (2)

More specifically in the medical career, the World Medical Federation generated three basic documents on global standards Medical Education. With regard to student support, it turned his attention to the processes of academic counseling and social, which must be guaranteed through a system to facilitate access to support, advice and career guidance. This based on tracking progress in training, information about problems that may arise, and be addressed to meet the social and personal needs of the students council (3).

In 2011 the American Medical Association (4) held a meeting whose main objective was to discuss strategies for optimizing the learning environment, and deepened about the topic violence (mistreatment), defining it as willful behavior or not showing a lack of respect for the dignity of others and unreasonably interferes with the learning process. Examples included sexual harassment, discrimination or harassment based on race, religion, ethnicity, gender or sexual orientation, physical or psychological punishment and the use of other forms of assessment and advice from a punitive way.

The Board presents results for 2010 and 2011, with a prevalence between 11 and $40 \%$ of abuse, consistent with earlier studies submitted in the United States and other countries (5-8). Which means that prior to the pronouncement of the American Medical Association, and Violence against students in undergraduate and graduate programs in medicine has been studied by several authors (9-11), who claimed that the professionals in medicine are likely to experience and likewise, perpetrate abuse and discrimination.

An example of this was the McMaster University in Canada (12), which in 1996 conducted a study on the prevalence of violence in medical students. Specifically for violence against women a prevalence of $71 \%$, for secondary violence of their sexual orientation was presented by $10.2 \%$ for sexual harassment was found was reported in $92.2 \%$ and physical violence, a finding not expected by researchers, was $54 \%$. This study proposed educational, behavioral and structural initiatives to incorporate into medical training programs to eradicate these practices.

Other studies have related the Gender-Based Violence (GBV) with the application of the scale and Maslach 
Burnout Inventory Leymman psychological horror in medical postgraduate students (13), finding that these conditions are presented in the same way in men and women but there depersonalization greater in women than in men.

In 2003, a study of prevalence of GBV in medical students from six colleges in Japan (14) was performed, finding that $68.5 \%$ of participants reported some type of violence. In the case of GBV, for their womanhood, sexual harassment appeared in $51.4 \%$ of the students. Violence beliefs, sexual orientation or race is not explored.

From a different conceptual perspective, in 2007, the group health and behavior of the Faculty of Medicine at the University New Granada raised the national study of bullying or intimidation (15) with the participation of 22 medical nationwide school level. The results observed in this study confirmed the presence of episodes of bullying in the field of higher education and more specifically, students in medical schools of the country by $19.68 \%$. This data was sufficient to give a voice alarm directives, teachers and students, showing that such phenomena are not a myth but a reality that is taking educational environments medical education in Colombia.

On the same line, the study characterizes the Gender-Based Violence in the students of the Military University Nueva Granada (16) identifying that this is a problem that is far from an isolated event took place or subtle. 94\% of those who provided answers to the questionnaire and reported having perceived Gender-Based Violence, went their sex, in this case, being female. Which it showed the importance of analyzing the conditions of violence against women in different areas.

At the same time, in recent years they have generated public policy (17) related to health promotion in educational settings. This strategy is called Healthy University or University Health Promoter. Which defined such institutions as those through the social distribution of knowledge, make strategic and sustained actions that promote comprehensive health (bio-psychosocial) and the active participation of the university community. This developing a culture of comprehensive health care, including the formation of healthy lifestyles and self-care, as well as opportunities and living environments, healthy work and learning, research and teaching within their substantive functions "(18).

The strategy is supported by international guidelines (see Table No.1), taking as a starting point the Alma Ata Health for All, which made visible to health as a fundamental right and raised the need for level actions social and economic environment for achieving it, until the formation of networks of Health Promoting Universities that are developing great strides in this area. A nationwide network of Promoting Universities (RED CUPS), has managed to integrate higher education institutions and produced a framework document aimed at raising awareness and institutional support (19), just as they advised the construction of guidelines for policy nationally (20). The

Table 1. List of national and international guidelines which support the Healthy University policies in Colombia.

\section{International Guidelines:}

- Stockholm Declaration on the Human Environment 1972

- Alma Ata Declaration of Health for All, 1978

- Kyoto Protocol to the United Nations Framework Convention on Climate Change (CMNUCC) 1987

- $\quad$ Second International Conference on Health Promotion 1.988

- Ottawa Charter for First International Conference on Health Promotion November 21, 1986

- Declaration of the International Conference on Health Promotion, Santa Fe de Bogota 1992

- The Caribbean Charter for Health Promotion 1993

- Jakarta Declaration on Health Promotion in the Twenty - First Century 1,997

- United Nations Conference on Environment and Development 1992 and 2002

- $\quad$ Fifth Global Conference on Health Promotion 2000

- WHO Framework Convention Snuff Control, Resolution WHA 56.1. 2003

- $\quad$ The Bangkok Charter for Health Promotion 2005

- IV International Congress of Health Promoting Universities Report 2009 
topics that are currently developing healthy eating, physical activity, cigarette-free, substance abuse, sexuality and inclusion. However, the presence of specific activities that are aimed at promoting the rights to physical and mental integrity are violated in situations of intimidation or in situations of gender-based violence is not evident.

\section{Discussion}

There are regional and national mechanisms aimed at promoting healthy and safe environments in the teaching of Higher Education, there are renowned for organizing educational institutions of higher education nationwide efforts. New Granada Military University as an institution actively involved in the network (Network of Health Promoting Universities). However, under carefully check their documents, its guidelines and projects, these are mainly focused on the healthy lifestyles (physical activity, prevention of use of psychoactive substances, discrimination and sexual and reproductive health) but do not address the issue of the right to a life free of violence as part of such lifestyles. What it is also reflected in specific activities or strategic actions.

Studies have been conducted to characterize the violence into medical school responding to the guidelines of the World Medical Federation and the American Medical Association, found that both intimidation or bullying as gender-based violence, are conditions in our context.

All this presents a challenge for integration from the Public Policy Health Promotion and inclusion of specific activities to to promote the right to live without violence in academic communities.

\section{Conflict of interests}

The authors declare that they have, directly or indirectly, any conflict of financial, academic and business interests that may jeopardize the validity of this study.

\section{Financing}

This work was conducted with the Universidad Militar de la Nueva Granada financial support.

\section{References.}

1. Constituyente AN. Constitución Política de Colombia. Colombia: UNESCO; 1991 p. Titulo II, Capitulo II, Articulo 67.

2. Ministerio de Educación Nacional. Ley 30 de Diciembre 28 de 1992. Colombia: Secretaria del Senado; 1992; p. 1.

3. Federación Mundial de Educación Médica. Estándares globales de la WFME para la Educación Médica. Educ Medica. 2004;7(2):5-60.
4. Rappley M. Section on Medical Schools. In: Optimizing the Learning Environment: Exploring the Issue of Medical Student Mistreatment [Internet]. Joint Education Program with the AMA Medical Student Section and AMA the Council on Medical Education; 2011; p. 2-14.

5. Arimatsu M, Wada K, Yoshikawa T, Oda S, Taniguchi H, Aizawa $Y$, et al. An epidemiological study of work-related violence experienced by physicians who graduated from a medical school in Japan. J Occup Health [Internet]. 2008;50(4):357-61.

6. Baldwin D, Daugherty S, Eckenfels E. Student Perceptions of Mistreatment and Harassment During Medical School A Survey of Ten United States Schools. West J Med. 1991;(155):140-5.

7. Cook DJ, Liutkus JF, Risdoni CL, Griffith LE, Guyatt GH, Walter S. Resident's experience of abuse, discrimination and sexual harassment during residency training. Can Med Assoc J. 1996;154(11):1657-65.

8. Risberg G, Johansson EE, Westman G, Hamberg K. Gender in medicine - An issue for women only ? A survey of physician teachers ' gender attitudes. Int J Equity Health. 2003;8:1-8.

9. Moreno-Cubillos C, Osorio-Gómez L, Sepúlveda-Gallego LE. Violencia sexual contra las estudiantes de la Universidad de Caldas. Estudio de corte transversal. Rev colomb Obs ginecol. 2007;58(2):116-23.

10. Morgan JF, Porter S. Sexual harassment of psychiatric trainees: experiences and attitudes. Postgrad Med J [Internet]. 1999;75(885):410-3.

11. Gadomski a M, Wolff D, Tripp M, Lewis C, Short LM. Changes in health care providers' knowledge, attitudes, beliefs, and behaviors regarding domestic violence, following a multifaceted intervention. Acad Med [Internet]. 2001;76(10):1045-52.

12. Margittai KJ, Moscarello R, Rossi MF. Forensic aspects of medical student abuse: a Canadian perspective. Bull Am Acad Psychiatry Law [Internet]. 1996 ;24(3):377-85.

13. Dikmeta E, Top M, Ergin G. An examination of mobbing and burnout of residents. Turkish $\mathrm{J}$ psychiatry [Internet]. 2011;22(3):137-49.

14. Nagata-Kobayashi S, Sekimoto M, Koyama H, Yamamoto W, Goto E, Fukushima O, et al. Medical student abuse during clinical clerkships in Japan. J Gen Intern Med [Internet]. 2006;21(3):212-8.

15. Paredes O, Sanabria-Ferrand P, González-Quevedo L, Moreno-Realphe S. "Bullying" en las facultades de medicina colombianas, mito o realidad. Rev Med. 2010;18(49):161-72.

16. Moreno-Realphe S, Sanabria-Ferrand P, Gonzalez-Quevedo L, Valencia-Cedeño C. ¿"Sutilezas" de la discriminación y la violencia basada en el género ? Situación de los y las estudiantes de pregrado y posgrado de una facultad de medicina en Bogotá D.C. Rev Med [Internet]. 2015;23(1):29-39.

17. Ministerio de Salud. Documento técnico: Promoviendo universidades saludables. Lima; 2010.

18. Universidad Colima. Propuesta de Modelo Nacional de Universidad Saludable Prevenimss. México; 2007.

19. Red Cups. Documento orientador. Bogota, Colombia; 2009.

20. Ministerio de Salud y Protección Social C. Universidades e Instituciones de Educación Superior (IES) Promotoras de Salud. Guía para su fortalecimiento y evaluación. Bogotá; 2012. 


\title{
A VIOLÊNCIA NA EDUCAÇÃO MÉDICA
}

\author{
SANDRA PATRICIA MORENO REALPHE ${ }^{1^{*}}$, Médica MSc. \\ PABLO ALFONSO SANABRIA FERRAND², Psicólogo, Epidemiólogo, MSc. \\ LUIS ARTEMO GONZÁLEZ QUEVEDO ${ }^{3}$, Psicólogo, Epidemiólogo, MSc. \\ CLAUDIA LUCÍA VALENCIA CEDEÑO ${ }^{4}$, Psicóloga, Especialista em Psicologia Clínica, MSc. \\ DOCENTES INVESTIGADORES DA FACULDADE DE MEDICINA. \\ UNIVERSIDADE MILITAR NUEVA GRANADA. \\ BOGOTÁ, COLOMBIA
}

\begin{abstract}
Resumo
O grupo de Saúde e Comportamento da Faculdade de Medicina e Ciências da Saúde tem centrado a sua investigação sobre a caracterização da violência no ambiente educacional da medicina a nível institucional e nacional. Este artigo refere-se aos resultados de estudos com relação ao assunto Bullying e Violência Baseada no Género e convida a uma reflexão sobre a importância da aplicação destes resultados para a vida diária do processo educativo; mediante a geração de estratégias que conduzem à construção de uma Universidade saudável.
\end{abstract}

Palavras-chave: Educação médica, violência, direitos humanos, política social, gênero.

\section{Introdução}

Na Colômbia, a Constituição refere-se à educação como um direito do indivíduo e um serviço público que tem uma função social. Além disso, "essa educação deve formar ao colombiano no respeito pelos direitos humanos, a paz e a democracia..." (1). A Lei 30 de 1992 por sua parte argumenta que o ensino superior é um processo contínuo e tem como missão desenvolver o potencial do ser humano de forma holística (2).

Mais especificamente na carreira de médico, a Federação Médica Mundial gerou três documentos básicos sobre os padrões globais de Educação Médica. No que respeita ao apoio ao estudante, a Federação focou sua atenção para os processos de aconselhamento acadêmico e social, que devem ser garantidos através de um sistema para facilitar o acesso ao apoio, aconselhamento e orientação profissional. Este conselho é baseado no acompanhamento dos progressos na formação, na informação sobre problemas que possam surgir e é destinado a satisfazer as necessidades sociais e pessoais dos alunos (3). Em 2011, a Associação Médica Americana (4) realizou uma reunião cujo principal objetivo foi discutir estratégias para aperfeiçoar o ambiente de aprendizagem e aprofundou sobre o tema da violência (misstreatment), definindo-a como um comportamento intencional que mostra falta de respeito pela dignidade dos outros e que, injustificadamente, interfere com o processo de aprendizagem. Alguns exemplos são o assédio sexual, discriminação ou assédio com base na raça, religião, etnia, gênero ou orientação sexual, castigo físico ou psicológico e o uso de outras formas de avaliação e aconselhamento de uma forma punitiva.

O Conselho apresentou os resultados de 2010 e 2011, com uma prevalência entre 11 e 40\% de abuso, consistentes com estudos anteriores apresentados nos Estados Unidos e em outros países (5-8). O que significa que, antes do pronunciamento da Associação Médica Americana, a violência contra os alunos em programas de graduação $e$ pós-graduação em medicina tem sido estudada por diversos autores (9-11), eles afirmam que os profissionais médicos são susceptíveis de experimentar, e da mesma forma, cometer abuso e discriminação.

Um exemplo disso foi a Universidade McMaster, no Canadá (12), que em 1996 realizou um estudo sobre a prevalência da violência em estudantes de medicina. Especificamente, a prevalência da violência contra as mulheres foi de 71\%, contra a sua orientação sexual foi $10.2 \%$, por assedio sexual foi $92.2 \%$ e a violência física, um descobrimento não esperado pelos pesquisadores, foi de 54\%. Este estudo propôs iniciativas educacionais, comportamentais e estruturais para incorporar em programas de treinamento médico, a fim de erradicar essas práticas. 
Outros estudos têm ligado a Violência Baseada no Género (VBG) através da aplicação da escala de Burnout de Maslach e o inventário de Leymman de terror psicológico nos alunos de pós-graduação de medicina (13), encontrando que estas condições ocorrem igualmente em homens e mulheres, mas há um maior grau de despersonalização em mulheres do que em homens.

Em 2003, foi realizado um estudo de prevalência de VBG em estudantes de medicina de seis faculdades no Japão (14), considerando que $68,5 \%$ dos participantes relataram algum tipo de violência. No caso da VBG, por sua feminilidade, o assédio sexual apareceu em $51,4 \%$ dos estudantes. A violência pelas crenças, orientação sexual ou raça não fora explorada.

A partir de uma perspectiva conceitual diferente, em 2007, o grupo de saúde e comportamento da Faculdade de Medicina da Universidade de Nueva Granada realizou o estudo nacional de Bullying ou intimidação (15) com a participação de 22 faculdades médicas em todo o país. Os resultados observados neste estudo comprovaram a presença de episódios de assédio moral na área do ensino superior e, mais especificamente, os alunos nas escolas médicas do país por 19,68\%. Estes dados foram suficientes para dar um grite de alarme às diretivas, os professores e os alunos, mostrando que tais fenômenos não são um mito, mas uma realidade que está tomando ambientes educacionais na educação médica na Colômbia.

No mesmo sentido, o estudo realizado caracterizou a Violência Baseada no Género Violência Baseada no Género Violência Baseada no Género nos estudantes da Universidade Militar Nueva Granada (16), no qual se identificou que este é um problema que está longe de ser um facto isolado ou sutil. O $94 \%$ das pessoas que forneceram respostas ao questionário, admitiram ser vítimas de Violência Baseada no Género por causa de seu sexo, neste caso, ser mulheres. O qual demostrou a importância de analisar as condições de violência contra as mulheres em diferentes áreas. Paralelamente, nos últimos anos tem sido criadas Políticas Públicas (17) relacionadas com a promoção da saúde em contextos educativos. Esta estratégia é chamada de Universidade Saudável ou Universidade Promotora de Saúde. A qual definiu aquelas instituições como as que através da distribuição social do conhecimento, fazem ações estratégicas e sustentáveis que promovem a saúde integral (bio-psico-social) e a participação ativa da comunidade universitária. Isto é devido ao desenvolvimento de uma cultura de atenção integral à saúde, incluindo a formação de estilos de vida saudáveis e de autocuidado, bem como as oportunidades e estilos de vida, trabalho $e$ aprendizagem saudáveis, também incluindo a investigação e ensino no âmbito das funções substantivas" (18).
A estratégia é apoiada por diretrizes internacionais (ver Quadro 1), tomando como ponto de partida a Declaração de Alma Ata, Saúde para todos, o que tornou a saúde como um direito fundamental e suscitou a necessidade de implementar ações para o nível social e econômico para o sucesso da mesma, até a formação de Redes de Universidades Promotoras de Saúde, as quais estão desenvolvendo grandes progressos nesta área. Nacionalmente, a rede de Universidades Promotoras (RED CUPS) tem podido integrar as Instituições de Ensino Superior e se uniram para elaborar um documento-quadro destinado à sensibilização e apoio institucional (19), da mesma forma aconselharam a construção de diretrizes para políticas a nível nacional (20).

Os temas que estão atualmente em desenvolvimento são a alimentação saudável, atividade física, vida livre de cigarro, uso de drogas, sexualidade e inclusão. No entanto, não se encontrou a presença de atividades específicas que vão destinadas a promover os direitos à integridade física $e$ mental, que são violados em situações de intimidação ou em situações de Violência Baseada no Género.

\section{Discussão}

Existem mecanismos regionais e nacionais destinados a promover ambientes de aprendizagem saudáveis e seguras no Ensino Superior, mas também há esforços não reconhecidos para a organização das Instituições Educativas de Ensino Superior a nível nacional. A Universidade Militar Nueva Granada participa ativamente na rede (Redes de Universidades Promotoras da Saúde). No entanto, quando os documentos quadros, alinhamentos $e$ projetos foram revisados, se encontrou que eles estão focados principalmente nos estilos de vida saudáveis (atividade física, prevenção do uso de substâncias psicoativas, discriminação e saúde sexual e reprodutiva), mas não abordam a questão do direito a uma vida livre de violência como parte de tais estilos de vida. O que tampouco se reflete em atividades específicas ou ações estratégicas.

Estudos têm sido realizados para caracterizar a violência dentro da escola de medicina respondendo às orientações da Federação Médica Mundial e da Associação Médica Americana, constatando que tanto a intimidação ou o assédio moral como a Violência Baseada no Género, são as condições mais presentes em nosso contexto.

Tudo isto representa um desafio na integração a partir da Política Pública de Promoção da Saúde e da inclusão de atividades específicas destinadas a promover o direito de viver sem violência em comunidades acadêmicas. 
Quadro 1. Lista das diretrizes nacionais e internacionais que apoiam a politica da Universidade Saudável na Colômbia.

\section{Diretrizes Internacionais:}

- Declaração de Estocolmo sobre o Ambiente Humano - 1972

- Declaração de Alma - Ata "Saúde para Todos" - 1978

- Protocolo de Quioto da Convenção - Quadro das Nações Unidas sobre Mudanças Clima (UNFCCC) - 1987

- Segunda Conferência Internacional sobre Promoção da Saúde - 1988

- Carta de Ottawa. Primeira Conferência Internacional sobre Promoção da Saúde - 21 de novembro de 1986

- Declaração da Conferência Internacional sobre Promoção da Saúde, Santa Fé de Bogotá $-1992$

- Carta do Caribe para a Promoção da Saúde - 1993

- Declaração de Jacarta sobre a Promoção da Saúde no Século XXI - 1997

- Conferências das Nações Unidas sobre Meio Ambiente e Desenvolvimento - 1992 e 2002

- Quinta Conferência Global sobre Promoção da Saúde - 2000

- $\quad$ Convenção - Quadro da OMS para o Controle do Tabaco, Resolução WHA 56.1 - 2003

- Carta de Bangkok para a Promoção da Saúde - 2005

- Relatório do IV Congresso Internacional de Universidades Promotoras da Saúde - 2009

\section{Conflitos de interesses}

Os autores declaram que não têm, direta ou indiretamente, qualquer conflito de interesses financeiros, acadêmicos o empresariais que possam pôr em risco a validade do presente estudo.

\section{Financiamento}

Este trabalho foi realizado com o apoio financeiro da Universidade Militar Nueva Granada.

\section{Referencias}

1. Constituyente AN. Constitución Política de Colombia. Colombia: UNESCO; 1991 p. Titulo II, Capitulo II, Articulo 67.

2. Ministerio de Educación Nacional. Ley 30 de Diciembre 28 de 1992. Colombia: Secretaria del Senado; 1992; p. 1.

3. Federación Mundial de Educación Médica. Estándares globales de la WFME para la Educación Médica. Educ Medica. 2004;7(2):5-60.

4. Rappley M. Section on Medical Schools. In: Optimizing the Learning Environment: Exploring the Issue of Medical Student Mistreatment [Internet]. Joint Education Program with the AMA Medical Student Section and AMA the Council on 
Medical Education; 2011; p. 2-14.

5. Arimatsu M, Wada K, Yoshikawa T, Oda S, Taniguchi H, Aizawa Y, et al. An epidemiological study of work-related violence experienced by physicians who graduated from a medical school in Japan. J Occup Health [Internet]. 2008;50(4):357-61.

6. Baldwin D, Daugherty S, Eckenfels E. Student Perceptions of Mistreatment and Harassment During Medical School A Survey of Ten United States Schools. West J Med. 1991;(155):140-5

7. Cook DJ, Liutkus JF, Risdoni CL, Griffith LE, Guyatt GH, Walter S. Resident's experience of abuse, discrimination and sexual harassment during residency training. Can Med Assoc J. 1996;154(11):1657-65.

8. Risberg G, Johansson EE, Westman G, Hamberg K. Gender in medicine - An issue for women only? A survey of physician teachers ' gender attitudes. Int J Equity Health. 2003;8:1-8.

9. Moreno-Cubillos C, Osorio-Gómez L, Sepúlveda-Gallego LE. Violencia sexual contra las estudiantes de la Universidad de Caldas. Estudio de corte transversal. Rev colomb Obs ginecol. 2007;58(2):116-23.

10. Morgan JF, Porter S. Sexual harassment of psychiatric trainees: experiences and attitudes. Postgrad Med J [Internet]. 1999;75(885):410-3.

11. Gadomski a M, Wolff D, Tripp M, Lewis C, Short LM. Changes in health care providers' knowledge, attitudes, beliefs, and behaviors regarding domestic violence, following a multifaceted intervention. Acad Med [Internet]. 2001;76(10):1045-52.

12. Margittai KJ, Moscarello R, Rossi MF. Forensic aspects of medical student abuse: a Canadian perspective. Bull Am Acad Psychiatry Law [Internet]. 1996 ;24(3):377-85.

13. Dikmeta E, Top M, Ergin G. An examination of mobbing and burnout of residents. Turkish $\mathrm{J}$ psychiatry [Internet]. 2011;22(3):137-49.

14. Nagata-Kobayashi S, Sekimoto M, Koyama H, Yamamoto W, Goto E, Fukushima O, et al. Medical student abuse during clinical clerkships in Japan. J Gen Intern Med [Internet]. 2006;21(3):212-8.

15. Paredes O, Sanabria-Ferrand P, González-Quevedo L, Moreno-Realphe S. "Bullying" en las facultades de medicina colombianas, mito o realidad. Rev Med. 2010;18(49):161-72.

16. Moreno-Realphe S, Sanabria-Ferrand P, Gonzalez-Quevedo L, Valencia-Cedeño C. ¿"Sutilezas" de la discriminación y la violencia basada en el género ? Situación de los y las estudiantes de pregrado y posgrado de una facultad de medicina en Bogotá D.C. Rev Med [Internet]. 2015;23(1):29-39.

17. Ministerio de Salud. Documento técnico: Promoviendo universidades saludables. Lima; 2010.

18. Universidad Colima. Propuesta de Modelo Nacional de Universidad Saludable Prevenimss. México; 2007.

19. Red Cups. Documento orientador. Bogota, Colombia; 2009.

20. Ministerio de Salud y Protección Social C. Universidades e Instituciones de Educación Superior (IES) Promotoras de Salud. Guía para su fortalecimiento y evaluación. Bogotá; 2012. 